\title{
FACTORS AFFECTING THE QUALITY OF REGIONAL FINANCIAL SUPERVISION
}

\author{
Aspihani Ahyat ${ }^{1)}$, Sri Rahayu ${ }^{2)}$, Susfa Yetti ${ }^{3)}$ \\ ${ }^{1,2,3)}$ Faculty of Economics and Bussiness, Universitas Jambi \\ Corresponding author: sri_rahayu@unja.ac.id; srijambi@gmail.com
}

\begin{abstract}
This research was conducted to analyze several factors that affected the quality of the inspectorate supervision, namely Independence, objectivity, expertise, due professional care, and accountability. Multiple regression analysis was chosen for this research, and the $F$ statistic test and $T$ statistic test were utilized for Hypothesis Test. The result indicated that (1) independence affected the quality of the inspectorate supervision, (2) objectivity affected the quality of the inspectorate supervision, (3) expertise affected the quality of the inspectorate supervision, (4) due professional care did not affect the quality of the inspectorate supervision, (5) accountability affected the quality of the inspectorate supervision. The influence of Independence, objectivity, expertise, due professional care, and accountability toward the inspectorate supervision had a strong coefficient of determination.
\end{abstract}

Keywords: Independence, Objectivity, Expertise, Due Professional Care, Accountability.

\section{Introduction}

As of the Internal Government Supervisory Apparatus (APIP), the regional inspectorate has a strategic role and position both in terms of management functions and achieving the vision, mission, and government programs. The internal government supervisory apparatus is in charge and serves to conduct supervision within the scope of its authority through audits, evaluations, monitoring, and other supervisory activities on the maintenance of duties and functions of institutions or organizations. Presidential Decree No. 16 of 2018 stated that APIP conducts internal supervision over the management of government agencies' duties and functions, including state financial accountability. In terms of essential functions of management, it has a position equivalent to the function of planning or implementation function. In contrast, in terms of achieving the vision, mission, and programs of the government, the regional inspectorate becomes a pillar that serves as a supervisor and a bodyguard in the implementation of the program contained in the Local Government Budget (APBD).

The internal audit function is to investigate and assess internal control and efficiency of implementing functions as organizational tasks. Thus the internal audit function is a form of control whose function is to measure and assess the effectiveness of other internal control elements. (Mulyadi, 2014). Therefore, the internal auditor of the local government plays a crucial role in creating accountability and transparency of financial management in the region. The role and function of the provincial inspectorate, district/city, in general, is stipulated in article 4 of Permendagri No. 64 of 2007, which states that in carrying out the duties of government affairs, provincial inspectorates, districts/cities have a function as planning supervisory programs and policy formulation supervision facilities as well as inspection, deprecation, testing, and assessment of supervisory duties.

Internal auditors, in carrying out their role, should pay attention to Independence. Independence reflects an impartial attitude and is not under pressure or a particular party in taking actions and decisions (Tuanakotta, 2011). Independence can be projected into four sub-variables, namely the first long relationship with the client (audit tenure), where the Indonesian government limits the auditor's working period to a maximum of only three years for the same client, while for the Public Accounting Firm (KAP) can be up to 5 years. The auditor is not too close to the client, so that it can prevent accounting scandals. Because the auditor is too close to the client, it will make the auditor satisfied with what he has done. The audit procedures he conducted become less assertive and depending on the management statement. So if shorter the length of the relationship with the client (audit tenure) will be the higher the auditor's Independence.

Other principles of conduct that apply to auditors include objectivity, integrity, and ethics. Objectivity is a quality that provides value for the services provided by members (Mulyadi, 2014). Objectivity is required so that auditors can act reasonably without being influenced by pressure or requests of certain interested parties on the results of audits and the competence of auditors supported by the knowledge and the ability necessary to carry out tasks. Integrity is required for auditors to act honestly and decisively in carrying out audits. In addition, auditors should also pay attention to their expertise and professionalism.

Expertise means auditors should have the knowledge, skills, and other competencies necessary to carry out their responsibilities. Auditors should use their professional expertise carefully and cautiously in each assignment. Professional care can be interpreted as a careful and cautious attitude by critically evaluating 
audit evidence, being careful in tasks, not careless in conducting inspections and having firmness in carrying out responsibilities (Agoes, 2012). Due professional care can be applied in professional judgment, although there may be improper withdrawal of conclusions when the audit has been conducted carefully. Auditors must comply with the established code of conduct. The implementation of the audit shall refer to this auditing standard, and the auditor shall comply with the code of conduct which is an integral part of the audit standard.

Carefulness and equality are the responsibility of every auditor. Accountability (responsibility) that must be owned by the auditor, namely the responsibility to the client and the responsibility of colleagues. Accountability is accountable for resource management and policy implementation entrusted to reporting entities in achieving periodic goals (Mulyadi, 2014).

Such attitudes, principles of conduct, expertise, and professionalism are essential for internal auditors to carry out the main task of supervision. In government organizations, financial supervision is an effort to recognize irregularities or obstacles in managing local government finances. The quality of regional financial supervision in Jambi Province has been implemented;. However, it still has to be continuously improved, and this is as conveyed by the deputy governor of Jambi when opening the Coordination Meeting of Regional Supervision (Rakorwasda) of the Government of Jambi Province, in the Hall of Inspectorate of Jambi Province (aksipost.com). The coordination meeting was conducted so that the Provincial Inspectorate and districts/cities carry out their duties and functions as bodyguards in coaching and supervision of the affairs of the respective municipal governments. The function of coaching and supervision to prevent potential noncompliance with the state's governance to prevent the possibility of potential corruption and administrative malls. However, for Jambi Province itself, the Internal Government Supervisory Apparatus (APIP) is still in the process of review (Jambi-independent.co.id). One of the phenomena in carrying out the supervisory function by the Jambi Provincial Inspectorate in the form of receiving 22 reports of complaints from the public related to the distribution of covid-19 assistance that had previously been budgeted by the Jambi provincial government with a total of Rp211 Billion for the handling of Covid-19 itself. Four of them were reported by the public because of mistargeting, such as members of civil servants who received assistance (tribunjambi.com).

Good quality of APIP supervision is expected to reduce regional financial management problems. Internal auditors who play a good role can also support good governance in government organizations (Rahayu, Yudi, and Rahayu, 2020). Therefore, the quality of supervision of regional financial management is essential so that it is expected to improve the quality of services for the community. The purpose of this study is to analyze the factors that affect the quality of regional financial supervision. Factors that are suspected to affect the quality of regional financial supervision are Independence, objectivity, expertise, due professional care, and accountability.

\section{Literature Review}

Jensen and Meckling first came up with the agency's theory in 1976. Agency theory discusses agency relationships in which a particular party (principal) delegates work to another party (agent) in the form of a cooperation contract. The main principle of agency theory states that there is a working relationship between the authority party (principal), namely stakeholders, and the party that receives the authority (agent), namely the manager.

The essence of supervision is to prevent as early as possible the occurrence of irregularities, waste, misappropriation, obstacles, errors, failures in the achievement of goals and the implementation of the tasks of an organization. Internal supervision is the entire process of auditing, reviewing, monitoring, evaluating, and other supervisory activities in the form of assistance, socialization, and consultancy on the implementation of organizational tasks and functions to provide adequate confidence that the activities have been carried out by the benchmarks that have been set effectively and efficiently for the benefit of leaders in realizing good governance (Regulation of the Minister of State Apparatus Utilization and Bureaucratic Reform No. PER/05/M.PAN/03/2008). Independence means it is not easily influenced and impartial to anyone because the auditor carries out his work in the public interest. Independence means a mental attitude that is free from any influence, uncontrollable, and independent of any party. Independence can also be interpreted by honesty in the auditor in considering facts and impartial, objective considerations in the auditor in formulating and expressing his opinion (Mulyadi, 2014). Independence is essential in producing quality supervision. Therefore auditors must have and maintain this attitude in carrying out their professional duties. Turangan (2016) and Puspita (2016) proved that Independence had a significant positive effect on the quality of supervision results. This shows that the higher the supervisory independence level, the better the quality of supervision produced by the inspectorate. The research is also consistent with this condition researched by Sari (2018) and Gunawan (2012). Independence is an essential factor that must be owned by an auditor in producing a quality audit. Auditors must maintain an independent mental attitude because the opinions from auditors aim to increase the credibility of the financial statements presented by management, so if the auditor is not independent, then the quality of supervision produced is not good.

Auditors who have objectivity are auditors who can conduct a balanced assessment of all relevant conditions and are not affected by their interests or the interests of others in making their decisions. 
Objectivity is a belief, quality that provides value for the services or services of auditors. Objectivity is one of the characteristics that distinguish the profession of accountants from other professions. The principle of objectivity establishes an obligation for auditors (public accountants) to be impartial, intellectually honest, and free from conflicts of interest (Wayan, 2005). According to Mulyadi (2014), objectivity is a mental attitude that auditors must maintain in conducting audits, and auditors should not allow their audit considerations to be influenced by other parties. Urrahmi (2015) found that the objectivity of the impact on the quality of regional financial supervision. The results of the study are in line with the results of research by Parasayu (2014) and Lestari (2013), which showed that objectivity has a significant effect on the quality of supervision, the higher the level of objectivity of auditors, the better the quality of the inspection results or supervision. An auditor should maintain the financial relationship with the client, as it is considered to affect the objectivity and may result in a third party concluding that the auditor's objectivity cannot be maintained.

Smith and Rahmatullah (2015) stated that expertise has an essential role in improving the quality of supervision. The positive influence shows that the influence of expertise is in the direction of the quality of supervision or other words, good/high expertise will affect the quality of supervision is good/high; on the contrary, if the expertise is low/insufficient, then the quality of supervision will be low/bad. Based on the Regulation of the Minister of State Apparatus Utilization and Bureaucratic Reform No. PER/05/M.PAN.03/2008, dated March 31, 2008, states that supervisors should have knowledge, skills, and other competencies treated to carry out their duties and responsibilities. APIP leaders should be confident that the supervisor's technical and educational competency background is adequate for the supervisor's work to be mandated. The audit profession demands high professionalism and expertise. Expertise is not only gained from formal education, but many other factors influence it, such as experience. Work experience has been seen as an essential factor in predicting the performance of public accountants, in this case, the quality of supervision.

Satria and Suprayitno (2015) research expertise on the quality of supervision. This research indicates that examiners who have adequate expertise can improve the quality of examination results better. Expert auditors have a better understanding. They are also better able to provide a reasonable explanation of errors in financial statements. They can group errors based on auditing goals and the structure of the underlying accounting system.

Cautious use of professional skills allows auditors to obtain sufficient confidence that financial statements are free from material misstatements, whether caused by errors or fraud. Careful auditors will be able to produce quality audits.

Ferdian and Malta (2018) researched due professional care on the quality of supervision. The results showed that due professional care has a significant effect on the quality of supervision. Professional proficiency and adequate confidence in the evidence found will greatly assist auditors in determining the scope and methodology to be used in carrying out audit work. Professional care has meaning of careful and thorough professional skills (PSA No. 04 SPAP 2001). Supervisors must maintain their professional knowledge and skills reasonably and diligently in applying their knowledge and skills when providing professional services. Thus, supervisors should refrain from providing services that do not have competence in carrying out such duties and must carry out their professional duties following all technical and professional standards (Elder et al., 2013).

Wiguna et al. (2017) researched the effect of accountability on the quality of supervision. The results showed that accountability positively affects the quality of audit results. The higher the accountability, the higher the quality of audit results. This is consistent with research conducted by Laksita and Sukirno (2019) and Karnia et al. (2015)

In theory, accountability (sense of responsibility) is part of the auditor's professional responsibility that during the performance of the auditor's duties must always perform with a sense of responsibility and must carry out the skills of the office carefully so that it will be obtained satisfactory work results and still enhance the reputation of the professionalism of the auditor.

Devotion to the profession is a commitment formed in a professional, without any coercion from anyone, and consciously responsible for the profession. Accountants should maintain their highest ethical standards of conduct to the organization they take refuge in, their profession, society, and their person. Accountants have a responsibility to be competent and maintain their integrity and objectivity. Accountability is one of the factors that affect the quality of supervision. According to Hafizh (2007) explaining accountability is a form of psychic motivation that makes a person responsible for all actions and decisions he takes. Central and local governments act as whistleblowers to fulfill public rights, namely the right to know, be informed, and be heard.

Based on the phenomena of the problem and the frame of thought, the researchers formulated the research hypothesis as follows:

H1: Independence affects the quality of supervision

$\mathrm{H} 2$ : Objectivity affects the quality of supervision

H3: Expertise affects the quality of supervision

H4: Due Professional Care affects the quality of supervision

H5: Accountability affects the quality of supervision 
H6: Independence, objectivity, expertise, due professional care, and accountability simultaneously affects the quality of supervision

\section{Research Method}

This research used the quantitative method. The population of this study amounted to 60 people consisting of the Supervisor of Implementation of Local Government Affairs (P2UPD) in the Provincial Inspectorate numbered about 29 people, and auditors numbered 31 people. The samples selected in this study have undergone a minimum assignment of 1 year, so that the number of samples becomes 55 people. The number of questionnaires returned by respondents and processed was 41 respondents $(74.54 \%)$.

Researchers used questionnaires for data collection. Respondents were asked to choose one statement that they thought best suited the four answer options, which are $1=$ strongly disagree, $2=$ disagree, $3=$ agree, and $4=$ strongly agree. The quality of supervision is the probability that auditors will find and report violations in the government accounting system based on accounting standards and audit standards that have been set. According to procedures, researchers used the quality indicators of supervision used by Mahanani (2018), namely the quality of the supervisory process and the carefulness in conducting supervision, according to procedures, while continuing to maintain skepticism. The indicators are outlined in the four questions in this research questionnaire. Independence reflects an impartial attitude and is not under pressure or a particular party in taking actions and decisions (Tuanakotta, 2011). Independent auditors in carrying out supervision will be free from organizational efforts to determine activities, cooperate, and not attach importance to personal interests. Independent reporting means reporting that is unaffected by others, does not lead to much interpretation, and discloses existing facts. Independence is measured by the Independence of the preparation of the program, the Independence of the implementation of the work, and the Independence of reporting. The study used seven-question items to measure the Independence of the government's internal auditors.

Objectivity is the auditors' attitude to be able to act pretty, not affected by cooperative relationships, and do not favor the interests of anyone so that auditors can be relied on and trusted. Objectivity is a quality that provides value for the services provided by members (Mulyadi, 2014). Auditors must disclose the conditions according to the facts, namely by expressing opinions as they are, not looking for errors on purpose, maintaining criteria/standards, and using logical thoughts. Objectivity in this study is determined based on being free from conflicts of interest and disclosure of conditions according to facts in the field. Researchers used eight-question items in the questionnaire for this variable. The expertise of the inspectorate auditors is the attitude of auditors who are increasingly becoming auditors, so it will make auditors have the ability to obtain relevant information, detect errors and find the cause of errors. The number of supervisory tasks performed by auditors makes auditors more thorough, can learn from previous mistakes, and quickly completes tasks. The expertise in this study was measured by the education, experience, and knowledge of the inspectorate auditors themselves (Smith and Rahmatullah, 2015). Indicators for this variable used seven research question items in the questionnaire.

Due professional care has the means of a caring attitude. Professional care can be interpreted as a careful attitude by critically evaluating audit evidence, being careful in tasks, not careless in conducting inspections and having firmness in carrying out responsibilities (Agoes, 2012). Carefulness and cautiousness require auditors to exercise professional skepticism, an attitude of auditors who think critically of evidence by constantly questioning and evaluating the evidence. The variables due to professional care in this study are measured based on that the inspectorate auditors use carefulness and skills in work, Have firmness in carrying out responsibilities, competent and careful in carrying out tasks, the possibility of errors, irregularities, and non-compliance, and alert to significant risks that can affect objectivity. Researchers pour in seven items of questionnaire questions.

Accountability is accountable for resource management and implementing policies entrusted to reporting entities in achieving periodic goals (Mulyadi, 2014). The accountability variables in this study are measured by indicators of the motivation of the inspectorate auditors to complete the audit task, the amount of effort (thinking power) given to complete the work, and confidence in the task carried out will be examined by the supervisor. Researchers used seven-question items for accountability variables.

Data analysis uses multiple regression with $\mathrm{f}$ test and t-test. Data quality is tested with validity tests and reliability tests. A validity test conducted by researchers using Pearson Correlation provided that if the correlation coefficient ( $r$ ) is positive and more significant than the $r$ table, it is stated that the statement item is valid. Reliability test using Cronbach alpha, with a value limit of more than 0.7 .

\section{Result and Discussion}

The respondents to this study were female primarily with 24 people or $58.53 \%$, while male respondents numbered 17 people or $41.47 \%$. Respondents grouped by education level showed that respondents with a bachelor's degree amounted to 38 people or $92.69 \%$ and master's degree amounted to 3 people or $7.31 \%$. This shows that respondents with bachelor's degrees have many people rather than other levels of education. Data shows that the respondent's education level is minimum at the level of bachelor's degree. This shows that the educational side of the respondent is good, so the respondents understand well each question in the questionnaire given. 
Researchers conduct data quality testing first before testing the hypothesis. Researchers set the signification rate at 0.05 . The validity test was conducted by researchers with Pearson Correlation, while the reliability test used Cronbach alpha, with a value of more than 0.7 . The data quality test results show that all indicators contained in the statement answered by the respondent meet the criteria to be declared valid and reliable.

Test $\mathrm{f}$ used by researchers to assess the research model. The results showed that the $\mathrm{p}$-value was at 0.015 less than 0.05 , which means that this research model is acceptable to continue to the next test. Multiple regression test results are presented in Table 1.

Tabel 1. Multiple Regression Analysis Results

\begin{tabular}{|c|c|c|c|c|c|}
\hline \multirow[b]{2}{*}{ Model } & \multicolumn{2}{|c|}{$\begin{array}{l}\text { Unstandardized } \\
\text { Coefficients }\end{array}$} & \multirow{2}{*}{$\begin{array}{c}\text { Standardized } \\
\text { Coefficients } \\
\text { Beta } \\
\end{array}$} & \multirow[b]{2}{*}{$\mathrm{T}$} & \multirow[b]{2}{*}{ Sig. } \\
\hline & $\mathrm{B}$ & Std. Error & & & \\
\hline (Constant) & 7,330 & 3,700 & & 1,981 &, 055 \\
\hline Independence & ,092 &, 116 & ,147 & 2,828 & 003 \\
\hline Objectivity & ,201 &, 125 & ,390 & 3,090 & 000 \\
\hline Expertise & ,260 &, 136 & ,430 & 1,910 & 001 \\
\hline DueProfessionalCare &, 124 &, 135 & ,212 & ,922 & ,363 \\
\hline Accountability &, 141 &, 152 & ,240 & 1,931 &, 038 \\
\hline
\end{tabular}

Source : Data Processed by Researchers

Based on the results of the multiple regression analysis, it can be obtained the regression equation as follows:

$\mathrm{Y}=7,330+$ 0,092Independence + 0,2010bjectivity + 0,260Expertise + 0,124DueProfesionalCare + 0,141 Accountability $+\mathrm{e}$

The coefficient of determination (R2) essentially measures how far the model can describe independent variable variations. The value of the coefficient of determination is indicated by the magnitude of the adjusted R2 value of 0.423 or $42.3 \%$. This shows that the influence of independent variables (Independence, objectivity, expertise, due professional care, and accountability) on dependent variables (quality of regional financial supervision) was $42.3 \%$, while $57.7 \%$ was influenced or explained by other variables not included in this research model such as motivation (Efendy, 2010), code of conduct (Ferdian \&Malta, 2018), and task complexity (Hari, 2015).

\section{Influence of Independence on The Quality of Regional Financial Supervision}

The results of this regression analysis show that Independence affects the quality of regional financial supervision. This is indicated by the p-value that the independent variable is $0.003(<0.05)$, and the coefficient of regression value shows a positive result, which is 0.092 . Thus, it can be concluded that there is a significant influence between Independence and the quality of regional financial supervision. This means that if there is an increase in the Independence of internal auditors, the quality of regional financial supervision will also increase. One of the strategies implemented by the inspectorate of Jambi Province to maintain Independence is required to rotate auditors, so there is no close relationship with the auditee. In addition, the inspectorate auditors also continue to report based on findings. Although many people doubt the Independence of internal auditors because of the shift in the role other than as a guaranteer in their supervision, internal auditors are also required to act as consultants and catalysts. In addition, the position as an internal part of the organization's internal structure also makes its Independence often questioned. However, the internal auditor still strives to maintain its Independence, especially in carrying out supervisory duties such as attestation services (audit or review) (Rahayu, Yudi, and Rahayu, 2018). The research conducted by Shintya et al. (2016) found empirical evidence that auditor independence positively and significantly affects the quality of supervision. The results of this study are also supported by research conducted by Ferdian and Malta (2018) which states that Independence has a significant effect on the quality of supervision. However, these results are inconsistent with Sari's research (2018) which states that Independence does not affect the quality of supervision.

\section{Influence of Objectivity on The Quality of Regional Financial Supervision}

The results of this regression analysis show that objectivity affects the quality of regional financial supervision. This is indicated by the significance level that the independent variable is $0.000(<0.05)$, and the coefficient of regression value shows a positive result, which is 0.201 . Thus, it can be concluded that there is a significant influence between objectivity and the quality of regional financial supervision. If there is an increase in the objectivity of internal auditors, there will also be an improvement in the quality of regional financial supervision. The objectivity of the inspectorate auditors includes free of any conflict of interest. According to the facts in the field, the inspectorate auditors must also disclose the facts without looking for 
errors on purpose. The inspectorate auditors, in this case, have implemented their objectivity so that is not influenced by subjective views. Objective inspectorate auditors will carry out the assignment professionally and refer to the standard operating procedures that have been established. This means that the application of reasonable objectivity will make better quality of supervision. Wardana and Ariyanto (2016) have researched the influence of objectivity on the quality of supervision results, and the results of auditor objectivity positively affect the quality of supervision. The results of this study are also supported by research conducted by Urrahmi (2015), which states that objectivity has a significant effect on the quality of supervision. This is not in line with the research conducted by Prabandari (2018), which states that objectivity does not affect the quality of supervision.

\section{Influence of Expertise on The Quality of Regional Financial Supervision}

The results of this regression analysis show that expertise affects the quality of regional financial supervision. This is indicated by the significance level that the independent variable is $0.001(<0.05)$, and the coefficient of regression value shows a positive result, which is 0.260 . Thus, it can be concluded that there is a significant influence between expertise and the quality of regional financial supervision. The expertise of the inspectorate auditors covers all the capabilities and knowledge of the inspectorate's auditors derived from formal education also supported by experience and practice in the field. The inspectorate auditors have qualified expertise so that through his expertise, the inspectorate auditors can learn actively in carrying out supervisory duties. Auditor experience will continue to increase along with the increasing number of audits conducted and the complexity of audited financial transactions of companies, thus increasing and expanding their knowledge in accounting and auditing (Agustina and Christiawan, 2015). Wirakusuma and Wulandari (2017) examined the influence of expertise on the quality of supervision, and the results of expertise positively influenced the quality of supervision. This means that the expertise of inspectorate auditors in carrying out duties professionally will affect the quality of supervision. The results of this study are in line with research conducted by Mahanani (2018), which states that expertise has a significant effect on the quality of regional financial supervision. However, the results of this study are not consistent with research conducted by Alamri et al. (2017), which states that expertise does not affect the quality of supervision.

\section{Influence of Due Professional Care on The Quality of Regional Financial Supervision}

This regression analysis shows that due professional care does not affect the quality of regional financial supervision. This is indicated by the significance level that the due professional care variable is 0.363 (> 0.05 ). This means that there is no significant influence between due professional care and the quality of regional financial supervision. This study showed that due professional care has no significant effect on the quality of supervision. This is due to the lack of intensity of the development of the expertise of the inspectorate auditors during the Covid-19 pandemic period compared to previous years. Then, not all required documents can be obtained quickly by the inspectorate auditors. Another factor is the limited time in carrying out supervisory activities and going down to the field to conduct direct interaction with the auditee. In a normal situation, a supervisor must maintain their professional knowledge and skills at a reasonably high level and be diligent in applying their knowledge and skills when providing professional services. Thus, supervisors should refrain from providing services that do not have competence in carrying out the task and must carry out their professional duties following all technical and professional standards (Elder et al., 2013). These results are consistent with Aisyah and Suwarno's (2017) research, which stated that due professional care does not affect the quality of supervision. This study also in line with research conducted by Wardani (2019), which states that due professional care does not affect the quality of supervision. However, the results of this study are not consistent with research conducted by Rusli et al. (2015) have researched the influence of due professional care on the quality of supervision, and the results of due professional care affect the quality of supervision.

\section{Influence of Accountability on The Quality of Regional Financial Supervision}

The results of this regression analysis show that accountability affects the quality of regional financial supervision. This is indicated by the significance level that the accountability variable is $0.038(<0.05)$, and the coefficient of regression value shows a positive result, which is 0.141 . Thus, it can be concluded that there is a significant influence between accountability and the quality of regional financial supervision. The results of this study show that accountability significantly affects the quality of supervision. This indicates that the indicators of motivation, the magnitude of thinking, and confidence of the inspectorate auditors on the tasks carried out significantly affect the quality of supervision produced by the inspectorate auditors. Public accountability is the provision of information and disclosure on the activities and financial performance of the government to interested parties with the report (Mardiasmo, 2018). Based on existing concepts and statistical test results stated that accountability could affect the quality of supervision. The higher the level of accountability, the better the quality of supervision produced. Research conducted by Sari (2015), Wiguna et al. (2017), and Karnia et al. (2015) found empirical evidence that accountability affects the quality of supervision. The results of this study are in line with research conducted by Wiguna et al. (2017), which states that accountability has a significant positive effect on the quality of supervision in inspectorates 
all over Bali. This is contrary to research conducted by Nandiri and Latrini (2015), Prihartini et al. (2015), and Marganingsih et al. (2016), which showed that auditor accountability does not affect the quality of supervision.

\section{Conclusion}

Based on the results and analysis discussed earlier, the researchers concluded that the results of this study proved empirically that Independence, Objectivity, Expertise, and Accountability affect the quality of supervision. However, Due Professional Care does not affect the Quality of Supervision. Local governments need to improve the Independence, objectivity, expertise continuously, and accountability of internal auditors to improve the quality of regional financial supervision. During the Covid-19 pandemic, supervisory strategies and auditors' professionalism are needed so that due professional care can still be improved.

This study has limitations, among others, research data derived from the answers of respondents submitted in writing with questionnaire instruments. Researchers do not use supporting data such as interviews and observations. Another limitation, the subject of this study is still in a small scope, namely only in the Inspectorate of Jambi Province. Therefore, researchers are further expected to use different research approaches and methods such as qualitative to disclose the quality of regional financial supervision. For upcoming researchers, they should expand on the subject of the study used. The provincial inspectorate and examine the inspectorate in the scope of districts/cities in Jambi Province. In addition, researchers can add other research variables such as motivation, leadership style, application of the code of conduct, and the complexity of tasks.

\section{References}

Agoes, Sukrisno. 2012. Auditing: Petunjuk Praktis Pemeriksaan Akuntan oleh Akuntan Publik. Jilid 1, Edisi 4, Jakarta: Salemba empat.

Agustina, M \& Christiawan, YJ. (2015). Pengaruh Good Corporate Governance terhadap Kinerja Perusahaan pada Sektor Keuangan, Business Accounting Review, Vol. 3, No. 1, pp. 223-232.

Aksi Post, 2017. Kualitas Pengawasan Daerah Harus Ditingkatkan, https://www.aksipost.com/2017/12/21/kualitas-pengawasan-daerah-harus-ditingkatkan/ diunduh 23 Maret 2020.

Alamri, Fitria, dkk. 2017. Pengaruh Keahlian, Pengalaman, Kompleksitas Tugas, dan Independensi Terhadap Audit Judgement Auditor Internal pada Inspektorat Provinsi Gorontalo. Jurnal Ekonomi, Manajemen, Bisnis, dan Akuntansi (EMBA) Universitas Sam Ratulangi.

Andayani, Wuryan. 2011. Audit Internal, Edisi Pertama, Penerbit: BPFE-Yogyakarta.

Aprita. 2016. Pengaruh Audit Kinerja, Pengawasan Fungsional, dan Pelaporan Kinerja Terhadap Akuntabilitas Publik. Skripsi (tidak dipublikasikan). Universitas Bangka Belitung.

Arens, Alvin. A, Randal J. Elder, Mark S. Beasley dan Jusuf, Amir. 2013. Jasa Audit dan Assurance Pendekatan Terpadu (Adaptasi Indonesia). Jakarta: Salemba Empat.

Badjuri, Achmad. 2011. Faktor-Faktor yang Berpengaruh Terhadap Kualitas Pengawasan Auditor Indpenden pada Kantor Akuntan Publik (KAP) di Jawa Tengah. Jurnal, Dinamika Keuangan dan Perbankan.

Efendy, Muh. Taufiq. 2010. Pengaruh Kompetensi, Independensi, dan Motivasi terhadap Kualitas Audit Aparat Inspektorat dalam Pengawasan Keuangan Daerah (Studi Empiris pada Pemerintah Kota Gorontalo). Tesis. Universitas Diponegoro

Fitriana. 2017. Analisis Faktor-Faktor yang Mempengaruhi Kualitas Hasil Pemeriksaan: Studi pada Inspektorat Provinsi Sumatera Selatan. Tugas Akhir (tidak dipublikasikan). Politeknik Negeri Sriwijaya. eprints.polsri.ac.id (Diakses pada 31 Januari 2020).

Hafizh, Muhammad. 2007. Pengaruh Pengalaman Kerja, Akuntabilitas, dan Objektivitas Auditor terhadap Kualitas Audit. Skripsi. Padang: Universitas Negeri Padang

Hendriksen, E. S., dan M. Breda. 1992. Accounting Theory. 5th Edition. USA: Richard D Irwin Inc.

Jacksen, I Wayan. 2011. Faktor-Faktor yang Mempengaruhi Kualitas Audit (Studi Empiris pada Badan Pengawas Keuangan Republik Indonesia Perwakilan Provinsi Jawa Tengah). Skripsi (tidak dipublikasikan). Universitas Katolik Soegijapranata Semarang.

Jambi Independent, 2019. Kapabilitas APIP Ada yang Masih Review. https://jambiindependent.co.id/read/2019/12/16/45549/kapabilitas-apip-ada-yang-masih-review. diunduh 7 Juli 2020

Jensen, M. C., dan W. H. Meckling. 1976. Theory of Firm: Managerial Behaviour, Agency Costs, and Ownership Structure. Journal of Financial Economics. Vol. 3. No. 4. Hal: 305-360.

Johannes, dkk. 2017. Pedoman Penulisan dan Bimbingan Skripsi. Fakultas Ekonomi dan Bisnis, Universitas Jambi.

Ikatan Akuntan Indonesia-Kompartemen Akuntan Publik (IAI-KAP). 2011. Standar Profesional Akuntan Publik. Jakarta. Salemba Empat.Sugiyono. 2019. Metode Penelitian Kuantitatif Kualitatif dan R\&D. Bandung: Alfabeta.

Komite SPAP Ikatan Akuntan Indonesia (IAI), (2001), Standar Profesional Akuntan Publik. Jakarta : Salemba Empat. 
Mardiasmo. 2018. Akuntansi Sektor Publik. Yogyakarta: Penerbit Andi.

Mulyadi. 2014. Auditing Buku 1. Jakarta: Salemba Empat.

Peraturan Kepala Badan Pengawasan Keuangan dan Pembangunan Nomor: PER- 362/K/04/2012 tentang Pedoman Probity Audit Pengadaan Barang/Jasa Pemerintah Bagi Aparat Pengawasan Intern Pemerintah (APIP). http://www.bpkp.go.id/uu/filedownload/8/105/2424.bpkp (Diakses pada 21 Januari 2020)

Peraturan Menteri dalam Negeri Nomor 8 Tahun 2009 tentang Pedoman Tata Cara Pengawasan atas Penyelenggaraan Pemerintahan Daerah.

Peraturan Menteri Negara Pendayagunaan Aparatur Negara Nomor PER/05/M.PAN/03/2008. Tentang Standar Audit Aparat Pengawas Intern Pemerintah.

Peraturan Pemerintah Nomor 60 Tahun 2008 tentang Sistem Pengendalian Internal Pemerintah (SPIP)

Peraturan Menteri Dalam Negeri Nomor 64 Tahun 2007 tentang Pedoman Teknis Organisasi dan Tata Kerja Inspektorat Provinsi dan Kabupaten/Kota.

Prabandari, Risti dan Kusumawati, Eny. 2018. Pengaruh Independensi, Motivasi Auditor, Pengalaman Kerja, Objektivitas, Due Professional Care, dan Akuntabilitas Terhadap Kualitas audt (Studi Empiris pada Kantor Akuntan Publik di Kota Surakarta dan Yogyakarta). Electronic Theses and Dissertations. Universitas Muhammadiyah Surakarta.

Rahayu, S, Yudi \& Rahayu, 2018, Strategi Penerapan Paradigma Baru dalam Peran Auditor Internal Organisasi Pemerintah, Journal of Applied Managerial Accounting, Volume 2, No 2, September 2018.

Sari, Yunita Nanda .2018. Pengaruh Kompetensi dan Independensi Terhadap Kualitas Audit dengan Etika Auditor Sebagai Variabel Moderasi (Studi Pada Kantor Akuntan Publik Di Kota Semarang).Skripsi, Unisbank Semarang.

Shintya, dkk .2016. Pengaruh Kompetensi, Independensi, dan Tekanan Anggaran Waktu terhadap Kualitas Audit.Jurnal, Fakultas Ekonomi dan Bisnis Universitas Trisakti.

Silalahi, Ulber. 2015. Metode Penelitian Sosial Kualitatif. Bandung: Refika Aditama

SPKN (Standar Pemeriksaan Keuangan Negara). Peraturan BPK RI No. 01 Tahun 2017. Ditama Binbangkum BPK RI.

Sri Rahayu, Yudi \& Rahayu | (2020) Internal auditors role indicators and their support of good governance, Cogent Business \& Management, 7:1, 1751020

Tuanakotta, Theodorus M. 2011. Berpikir Kritis Dalam Auditing. Salemba Empat, Jakarta.

Usman, Husnaini dan Purnomo, Setiadi. 2009. Metodologi Penelitian Sosial. Jakarta: Bumi Aksara.

Wardana, Made Aris dan Ariyanto, Dodik. 2016. Pengaruh Gaya Kepemimpinan Transformasional, Objektivitas, Integritas, dan Etika Auditor Terhadap Kualitas Audit. Jurnal. Fakultas Ekonomi dan Bisnis Universitas Udayana.

Wirakusuma, Made Gede dan Wulandari, Luh Gede Ayu Nidya. 2017. Pengaruh Independensi, Keahlian Audit, Pengalaman dan Besaran Fee Audit Terhadap Kualitas Audit. Jurnal. Fakultas Ekonomi dan Bisnis Universitas Udayana.

Wiratama, William Jefferson Dan Budiartha, Ketut. 2015. Pengaruh Independensi, Pengalaman Kerja, Due Professional Care danAkuntabilitas Terhadap Kualitas Audit .Jurnal, Fakultas Ekonomi dan Bisnis Universitas Udayana.

Zulkifli, 2020. Inspektorat Terima 22 Laporan Penyelewengan Bansos Covid-19, Ada PNS Jambi Terima Batuan, https://jambi.tribunnews.com/2020/06/22/inspektorat-terima-22-laporan-penyelewengan-bansoscovid-19-ada-pns-jambi-terima-batuan. diunduh 7 Juli 2020. 